\title{
Antibiotics as an adjunct to phenol matrixectomy did not decrease healing time of ingrown toenails
}

\author{
Reyzelman AM, Trombello KA, Vayser DJ, et al. Are antibiotics necessary in the treatment of locally infected ingrown \\ toenails? Arch Fam Med 2000 Sep/Oct;9:930-2.
}
QUESTION: In patients with infected ingrown toenails, is the addition of oral antibiotics to phenol matrixectomy more effective than matrixectomy alone in decreasing healing time?

Design

Randomised (allocation concealed*), unblinded,* controlled trial with follow up to healing.

Setting

Outpatient clinic in San Antonio, Texas, USA.

\section{Patients}

154 patients who were $10-60$ years of age (mean age 21 y, $59 \%$ men) and had locally infected ingrown nails of the big toe (nail borders exhibited paronychia, granulation tissue, oedema, and the presence of exudates). Exclusion criteria were immunocompromised states (long term steroid use, diabetes mellitus, collagen vascular disease, or HIV infection), cellulitus proximal to the interphalangeal joint, or peripheral vascular disease. 148 patients $(96 \%)$ were included in the analysis.

\section{Intervention}

Patients were allocated to a 1 week course of oral antibiotics (cephalexin, 500mg, 4 times/d) and simultaneous phenol matrixectomy at the initial visit $\left(\mathrm{AM}_{\mathrm{s}}\right)(\mathrm{n}=53)$, oral antibiotics at the initial visit and phenol matrixectomy 1 week later $\left(\mathrm{AM}_{\mathrm{w}}\right)(\mathrm{n}=51)$, or phenol matrixectomy at the initial visit $(M)(n=50)$.

\section{Main outcome measure}

Healing time (interval between matrixectomy and resolution of drainage and inflammatory changes around the nail border).

\section{Main results}

Healing occurred sooner among patients in the $\mathrm{AM}_{\mathrm{s}}$ group than among patients in the $\mathrm{AM}_{\mathrm{w}}$ group $(\mathrm{p}<0.04)$ (table). Healing times did not differ between the $\mathrm{AM}_{\mathrm{s}}$ and

Source of funding: none stated.

For correspondence: Dr K A Trombello, Ankle and Foot Clinic, 1114 Broadway Street, Longview, WA 98665 , USA. Fax +1360577 1871
$\mathrm{M}$ groups $\{\mathrm{p}=0.50\} \uparrow$ (table).

\section{Conclusion}

In patients with infected ingrown toenails, the addition healing time more than matrixectomy alone.

*See glossary.

$\uparrow \mathrm{p}$ Value calculated from data in article. of oral antibiotics to matrixectomy did not decrease
Antibiotics plus simultaneous phenol matrixectomy ( $\left.A M_{s}\right)$, antibiotics plus matrixectomy 1 week later $\left(A M_{w}\right)$, and matrixectomy $(M)$ alone for ingrown toenails $\ddagger$

\begin{tabular}{lll} 
Comparison & $\begin{array}{l}\text { Healing times } \\
\text { (wks) }\end{array}$ & $\begin{array}{l}\text { Mean difference } \\
(95 \% \mathrm{Cl})\end{array}$ \\
$\mathrm{AM}_{\mathrm{s}} v \mathrm{AM}_{\mathrm{w}}$ & $1.9 v 2.3$ & $0.4(0.1$ to 0.7$)$ \\
\hline $\mathrm{AM}_{\mathrm{s}} v \mathrm{M}$ & $1.9 v 2.0$ & $0.1(-0.2$ to 0.4$) \S$ \\
\hline
\end{tabular}

$\neq \mathrm{Cl}$ defined in glossary; mean difference and $\mathrm{Cl}$ calculated from data in article. $\S$ Not significant.

\section{COMMENTARY}

Reyzelman et al provide a cogent argument for avoiding systemic antibiotics when using chemical matrixectomies to manage infected ingrown toenails. Healing time did not differ with phenol matrixectomies and nail border removal with or without concurrent administration of a typical oral regimen of cephalexin. Indeed, they found that healing time is prolonged if antibiosis is started a week before phenol matrixectomy. The authors correctly point out that unnecessary antibiosis contributes to clinical antibiotic resistance (and super infection) and adds to treatment cost.

Chemical (phenol) matrixectomy, as described by Dagnall, ${ }^{1}$ has been done with minor variations for over 100 years with good success. On the basis of a meta analysis of randomised and quasirandomised trials, Rounding and Hulm concluded that phenol treatment is more effective in preventing recurrence than is surgical excision alone but it carries an increased risk for postoperative infection. ${ }^{2}$

Given these earlier results, one must be mildly concerned that in the study by Reyzelman et al, 2 of 47 patients (4.3\%) who had chemical matrixectomies alone, compared with no patients in the antibiotic treated group, had postoperative infections. Nevertheless, phenol matrixectomy without antibiotics can be considered an appropriate technique for the treatment of moderately infected ingrown toenails.

Allan S Goldberg, DPM St.John's Episcopal Hospital-South Shore Far Rockaway, New York, USA

1 Dagnall JC. A description of toenail matrix phenolisation 44 years before Boll's 1945 paper. The Foot 1991;1:51-5.

2 Rounding C, Hulm S. Surgical treatments for ingrowing toenails. Cochrane Database Syst Rev 2000;(2):CD001541. 